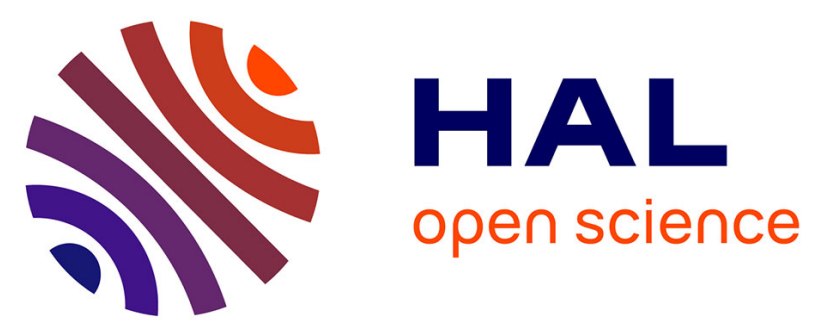

\title{
The Diffusion of the Strategic Plan for Biodiversity and Its Aichi Biodiversity Targets within the Biodiversity Cluster: An Illustration of Current Trends in the Global Governance of Biodiversity and Ecosystems
}

Guillaume Futhazar

\section{To cite this version:}

Guillaume Futhazar. The Diffusion of the Strategic Plan for Biodiversity and Its Aichi Biodiversity Targets within the Biodiversity Cluster: An Illustration of Current Trends in the Global Governance of Biodiversity and Ecosystems. Yearbook of International Environmental Law, 2016, 25, pp.133 166. 10.1093/yiel/yvv061 . halshs-01477899

\author{
HAL Id: halshs-01477899 \\ https://shs.hal.science/halshs-01477899
}

Submitted on 27 Feb 2017

HAL is a multi-disciplinary open access archive for the deposit and dissemination of scientific research documents, whether they are published or not. The documents may come from teaching and research institutions in France or abroad, or from public or private research centers.
L'archive ouverte pluridisciplinaire HAL, est destinée au dépôt et à la diffusion de documents scientifiques de niveau recherche, publiés ou non, émanant des établissements d'enseignement et de recherche français ou étrangers, des laboratoires publics ou privés. 
The Diffusion of the Strategic Plan for Biodiversity and Its Aichi Biodiversity Targets within the Biodiversity Cluster: An Illustration of Current Trends in the Global Governance of Biodiversity and Ecosystems

\author{
Guillaume Futhazar
}

Ph.D Candidate on contract for the OT-Med Labex under the supervision of the CERIC (CERIC - CNRS UMR 7318, Aix Marseille University). Contact: guillaume.futhazar@etu.univ-amu.fr.

\title{
I. INTRODUCTION
}

2010 left observers with doubts and uncertainties concerning the preservation of biodiversity and ecosystems on a global scale. ${ }^{1}$ The 2010 objective for biodiversity ${ }^{2}$ had not been met, and this situation was recognized with alarm by the whole international community. ${ }^{3}$ As officially stated by the Convention on Biological Diversity (CBD), swift actions had to be taken in order to tackle the massive erosion of biodiversity that had been underlined by so many experts. ${ }^{4}$ That same year, the CBD Conference of the Parties (COP), which was held in Nagoya, issued several decisions reflecting the international community's attempt to establish the necessary framework to halt the decline of world biodiversity. ${ }^{5}$ Among those decisions, a

\footnotetext{
This article is a contribution on two different initiatives: The Circulex project (ANR-12-GLOB-0001-03 CIRCULEX), funded by the French National Agency for Research, whose purpose is to study the circulation of norms and actors in international environmental governance, and the Labex OT-Med ( ${ }^{\circ}$ ANR-11-LABX-0061) funded by the French Government 'Investissements d'Avenir' program of the French National Research Agency (ANR) through the A*MIDEX project (Doc ANR-11-IDEX-0001-02). The purpose of the Labex is to study global change and natural hazards in the Mediterranean basin and semi-arid regions of Sahel. More information can be found at http://www.otmed.fr.

1 'International Failure to Meet Target to Reduce Biodiversity Decline' The Guardian (29 April 2010)

<http://www.theguardian.com/environment/2010/apr/29/international-failure-biodiversity-decline>.

${ }^{2}$ Strategic Plan for the Convention on Biological Diversity, Doc UNEP/CBD/COP/6/20 (2002) 317-22.

${ }^{3}$ Convention on Biological Diversity (CBD), Global Biodiversity Outlook 3, at 9 (2010): 'The target agreed by the world's Governments in 2002, "to achieve by 2010 a significant reduction of the current rate of biodiversity loss at the global, regional and national level as a contribution to poverty alleviation and to the benefit of all life on Earth," has not been met.'

${ }^{4}$ CBD, New Vision Required to Save Off Dramatic Biodiversity Loss, Says UN Report <Press Release> (there is no document number) (2010) <http://www.cbd.int/doc/press/2010/pr-2010-05-10-gbo3-en.pdf .

${ }^{5}$ Forty-seven decisions were adopted. It was the first time so many decisions were adopted at a CBD Conference of the Parties (COP).
} 
new strategic plan for the coming decade was adopted: the Strategic Plan for Biodiversity 2011-20 and the Aichi Biodiversity Targets (SPB). ${ }^{6}$

This new strategic plan goes further than its predecessor in several different ways. First, its architecture is far more developed than the previous plan's. With a carefully explained rationale, the new plan introduces five strategic goals (from A to E) and twenty 'Aichi Biodiversity Targets' distributed among these strategic goals. For example, under Strategic Goal A: Address the Underlying Causes of Biodiversity Loss by Mainstreaming Biodiversity across Government and Society, one finds four different Aichi targets among which Target no. 1 states: 'By 2020, at the latest, people are aware of the values of biodiversity and the steps they can take to conserve and use it sustainably.' Compared to the previous plan, this one focuses more on the role and place of human beings within their environment. Second, the members of the CBD did not simply state a new plan but also added sections related to the implementation and support of the different goals and objectives. ${ }^{7}$ The failure to meet the 2010 objective increased awareness of what was needed to see the new strategic plan succeed.

Although initially adopted within the CBD fora, the new plan has been subsequently incorporated into other decisions and resolutions of specialized international conventions in the field of biodiversity and ecosystems. This is a clear example of normative diffusion among the global instruments of the biodiversity cluster. Moreover, as noted by John E. Scanlon, the secretary-general of the Convention on International Trade in Endangered Species of Wild Fauna and Flora (CITES), 'it was the first time the [CITES] CoP had ever incorporated into its decisions a decision taken in another forum. ${ }^{98}$ This statement raises several questions. Was it truly a first? How significant is the diffusion of the strategic plan and its objectives for the global governance of biodiversity and ecosystems? Are we facing a conceptual revolution in this field or is it just an unremarkable singularity?

Following COP-12 to the CBD and half way through the timeline of the current plan, these interrogations added to the already substantial discussions on global biodiversity governance. This article provides an international environmental law perspective on this topic. In order to answer these questions, the first section will study in detail the diffusion of the

\footnotetext{
${ }^{6}$ The Strategic Plan for Biodiversity 2011-2020 and the Aichi Biodiversity Targets, Doc UNEP/CBD/COP/DEC/X/2 (2010) [Strategic Plan for Biodiversity].

7 Ibid.

${ }^{8}$ Meas Different Approaches in Support of Implementation of the Overall Strategic Plan for Biodiversity, Statement by CITES Secretary-General at SBSTTA side-event (2013), <http://cites.org/eng/news/sg/2013/20131016_sbstta17_side-event.php>. Convention on International Trade in Endangered Species of Wild Fauna and Flora, 993 UNTS 243 (1973).
} 
strategic plan and its objectives. The answers to simple interrogations such as 'where,' 'who,' or 'how' will provide elements to better comprehend the issues at stake in the global governance of biodiversity. One of the main findings of this first section is that the diffusion of the SPB was successful thanks to the cooperation of the different Secretariats of the biodiversity cluster. The second section will then focus on analysing the different effects of this diffusion. This analysis will focus on the isolated effect of the diffusion of the SPB and its targets in other conventions and then discuss the potential effect of the diffusion as a whole in the biodiversity cluster. This investigation will illustrate the fact that while the incorporation of the SPB into other strategic plans has little effect on its own, the cumulative effect of the diffusion associated with other decisions taken within the biodiversity cluster can have a significant influence on the governance of global biodiversity and ecosystems.

\section{A SUCCESFUL DIFFUSION ILLUSTRATING THE ROLE OF DISCREET ACTORS IN ENVIRONMENTAL}

GOVERNANCE: THE SECRETARIATS

The SPB diffusion occurred in a wide range of regimes that are linked to biodiversity and ecosystem issues, and it has taken many forms, from explicit partnerships to communications on existing activities already contributing to the SPB or on the possibilities for improved synergies. Through the United Nations Information Portal on Multilateral Agreements (InforMEA), for example, several international institutions representing different regimes, such as trade or health, have indicated how their respective activities match with the different Aichi Biodiversity Targets of the SPB. ${ }^{9}$

\footnotetext{
${ }^{9}$ This website set up by the United Nation Information Portal on Multilateral Environmental Agreements (InforMEA) gives a clear and synthetic overview of the general scope of the Strategic Plan for Biodiversity 2011-20 (SPB) and Aichi Biodiversity Targets' diffusion: <http://ieg.informea.org/>. For instance, the United Nations Conference on Trade and Development (UNCTAD) has a wide array of activities that align with the Aichi Biodiversity Targets. The first UNCTAD BioTrade Congress, held in 2012, addressed ways in which it could contribute to meet the SPB and its Aichi Target and highlighted how its ongoing projects are already working towards sustainability and higher awareness of the values of biodiversity among stakeholder. In the health context, the World Health Organization, has published a report in 2012, underlining the place of health within the SPB and its targets and stressing the 'opportunities for better linkages of biodiversity and health goals.' Some institutions have integrated the Aichi targets within their own framework in a more formal way. The FAO's Commission on Genetic Resources for Food and Agriculture (CGRFA), at its fifteenth regular session, highlighted the fact that the Aichi Biodiversity Targets are now being used as indicators in order to monitor the implementation of the voluntary guidelines to support the integration of genetic diversity into national climate change adaptation planning. The commission also requested its Secretariat to ensure that the upcoming global report on the State of the World's Biodiversity for Food and Agriculture contributes to the SPB and its target. This strong implication of the CGRFA is understandable as its mandate is closely in line with Aichi Target 13: minimizing genetic erosion and safeguarding genetic diversity.
} 
The political outreach of the SPB is significant and can be witnessed at all levels, from the global to the regional and the local (for instance, the European Union (EU) has also incorporated the Aichi Biodiversity Targets). ${ }^{10}$ This article is focused on the diffusion of the SPB in what has been referred to as the 'biodiversity cluster.' 11 This term describes the main multilateral environmental agreements (MEAs) in the field of biodiversity and ecosystems, which are listed in chronological order as: the Convention on Wetlands of International Importance Especially as Waterfowl Habitat (Ramsar Convention), ${ }^{12}$ the Convention for the Protection of the World Cultural and Natural Heritage (World Heritage Convention), ${ }^{13}$ CITES, ${ }^{14}$ the Convention on Migratory Species of Wild Animals (CMS), ${ }^{15}$ the CBD, ${ }^{16}$ and the International Treaty on Plant Genetic Resources for Food and Agriculture (ITPGRFA). ${ }^{17}$ The diffusion of the SPB in this cluster underlines both the cooperation dynamics existing within this cluster and the success of the SPB when compared to previous cases of diffusion. In addition, by taking a closer look at the different actors involved in the discussions that led to the diffusion of the SPB, it appears clearly that the Secretariats have been proactive in acting as brokers for this diffusion. As such, this situation underlines the current role that Secretariats can play in the global governance of biodiversity and ecosystems.

\section{The Strategic Plan within the Biodiversity Cluster}

This section describes how the MEAs incorporated the SPB into their own normative structure. In this article, 'normative structure,' or 'normative corpus,' is understood to be all of the decisions of the MEA bodies that can have a legal influence on the member states. Following this rationale and in the context of our analysis, decisions 'taking note' of the SPB and its targets are not considered to be part of the normative corpus since their legal influence

\footnotetext{
${ }^{10}$ Aichi Biodiversity Targets, <http://biodiversity.europa.eu/policy/target-1-and-related-aichi-targets>.

${ }^{11}$ For example, UNEP-WCMC, Promoting Synergies within the Cluster of Biodiversity-Related Multilateral Environmental Agreements (2012). It is important to note here that the term 'cluster' covers a wide array of situations reflecting various degrees of cooperation among multilateral environmental agreements (MEAs). For instance, the 'biodiversity cluster' is far less integrated than the 'chemical cluster,' yet both share the same denomination. Clustering simply aims at increasing efficiency and effectiveness of MEAs with overlapping purposes. See S Oberthür, Clustering of Multilateral Agreements: Potentials and Limitations 2 International Environmental Agreements 317 at 318 (2002). This objective is attained through different means depending on the specificities and history of the cooperating MEAs.

${ }^{12}$ Convention on Wetlands of International Importance Especially As Waterfowl Habitat, 996 UNTS 245 (1971) [Ramsar Convention].

${ }^{13}$ Convention for the Protection of the World Cultural and Natural Heritage, 1037 UNTS 151 (1972).

${ }^{14}$ Convention on International Trade in Endangered Species of Wild Fauna and Flora, 993 UNTS 243 (1973).

${ }^{15}$ Convention on the Conservation of Migratory Species of Wild Animals, 1651 UNTS 333 (1979) [CMS].

${ }^{16}$ Convention on Biological Diversity, 1760 UNTS 79 (1992).

${ }^{17}$ International Treaty on Plant Genetic Resources for Food and Agriculture, 2400 UNTS 303 (2001).
} 
is close to non-existent on this subject. Following this analysis, the second section aims at comparing the present diffusion to past cases in order to evaluate John E. Scanlon's statement: 'Is it truly a first'? 18

\section{A. A Protean and Swift Diffusion}

The SPB 2011-20 expressly calls for cooperation among the MEAs. ${ }^{19}$ The diffusion of the SPB can thus be seen to be simply one of several responses by the relevant conventions to this request for cooperation. A short analysis of the diffusion process in the other MEAs of the biodiversity cluster highlights the fact that the circulation pattern for the SPB was roughly the same within CITES, the CMS, and the Ramsar Convention. For those MEAs, the SPB was first discussed during the meeting of their permanent bodies and later endorsed by the plenaries so as to incorporate the SPB and its targets in the respective strategic plans of the different MEAs. In the cases of the World Heritage Convention and the ITPGRFA, because of their own specificities, the SPB and its Aichi Biodiversity Targets were only 'noted' by the different bodies of those MEAs.

In the fora of the World Heritage Convention, the first mention of the SPB and its Aichi Biodiversity Targets was made in 2013 during the thirty-seventh session of its committee, which was held Phnom Penh. The committee adopted a decision ${ }^{20}$ in which it called for state members to 'ensure their National Biodiversity Strategy and their Action Plans (NBSAP) fully consider the importance of natural World Heritage sites to achieve the Aichi Biodiversity Targets. ${ }^{, 21}$ In this particular case, there is no incorporation of the SPB in a strategic plan, only an invitation to states to ensure that the fulfilment of their obligations under the CBD is coherent with the aim of the World Heritage Convention and an indication that the convention can contribute to the newly set targets.

The case of the ITPGRFA is also particular. The SPB was not incorporated in a strategic plan or similar framework for the treaty; however, the links between the ITPGRFA and the CBD are such that there seems to be no imperative need to incorporate the SPB and its targets in the normative corpus of the treaty. Indeed, Article 1 of the treaty clearly states

\footnotetext{
${ }^{18}$ MEAs Different Approaches in Support of Implementation of the Overall Strategic Plan for Biodiversity, supra note 8 .

${ }^{19}$ Strategic Plan for Biodiversity, supra note 6 at 4, 10.

${ }^{20}$ Decisions Adopted by the World Heritage Committee at Its Thirty-seventh Session (Phnom Penh, 2013), Decision 37 COM 5A, Doc WHC-13/37.COM/20 (2013) at 4.

${ }^{21}$ Ibid.
} 
that its objectives are 'in harmony with the Convention on Biological Diversity' and will be attained by closely linking the treaty to the CBD. In addition, considering the fact that the ITPGRFA had been adopted within the framework of the Food and Agriculture Organization and that this organization was taking steps to take the SPB into consideration (through its Commission on Genetic Resources for Food and Agriculture), ${ }^{22}$ it seems that, contrary to the Ramsar Convention, CITES, and the CMS, the incorporation of the SPB in a strategic plan, although not formal, could be considered to be 'automatic.'

${ }^{22}$ Report of the Commission on Genetic Resources for Food and Agriculture, Doc CGRFA-14/13/Report (2013), paras 19-27. Two main points are to be noted in this extract of the report. First, the Food and Agriculture Organization (FAO) is requested to 'to strengthen work on targets and indicators in relation to the implementation of the Strategic Plan for Biodiversity 2011-2020 and the monitoring of the Aichi Biodiversity Targets.' Second, the commission adopts new indicators for the implementation of its strategy. These indicators aim to contribute to the SPB and its targets. 
Table 1: Simplified Timeline of the Circulation of the SPB and Its Targets within the Biodiversity Cluster

\begin{tabular}{|c|c|c|c|c|c|}
\hline & 2010 & 2011 & 2012 & 2013 & 2014 \\
\hline $\begin{array}{l}\text { Ramsar } \\
\text { Convention }\end{array}$ & & $\begin{array}{l}\text { November } \\
\text { 2011: forty- } \\
\text { third meeting } \\
\text { of the } \\
\text { Standing } \\
\text { Committee }\end{array}$ & $\begin{array}{l}\text { July 2012: } \\
\text { COP-10 of } \\
\text { the Ramsar } \\
\text { Convention }\end{array}$ & & \\
\hline $\begin{array}{l}\text { World } \\
\text { Heritage } \\
\text { Convention }\end{array}$ & & & & $\begin{array}{l}\text { June 2013: } \\
\text { thirty- } \\
\text { seventh } \\
\text { session of } \\
\text { the World } \\
\text { Heritage } \\
\text { Committee }\end{array}$ & \\
\hline CITES & & $\begin{array}{l}\text { August } \\
\text { 2011: sixty- } \\
\text { first meeting } \\
\text { of the } \\
\text { Standing } \\
\text { Committee }\end{array}$ & $\begin{array}{l}\text { July 2012: } \\
\text { sixty-second } \\
\text { meeting of } \\
\text { the Standing } \\
\text { Committee }\end{array}$ & $\begin{array}{l}\text { March } \\
\text { 2013: } \\
\text { COP-13 of } \\
\text { CITES }\end{array}$ & \\
\hline CMS & $\begin{array}{l}\text { November } \\
2010 \text { : } \\
\text { thirty- } \\
\text { seventh } \\
\text { meeting of } \\
\text { the Standing } \\
\text { Committee }\end{array}$ & $\begin{array}{l}\text { November } \\
2011: \\
\text { COP-10 of } \\
\text { the CMS }\end{array}$ & $\begin{array}{l}\text { November } \\
2012 \text { : } \\
\text { fortieth } \\
\text { meeting of } \\
\text { the Standing } \\
\text { Committee }\end{array}$ & $\begin{array}{l}\text { November } \\
2013 \text { : } \\
\text { forty-first } \\
\text { meeting of } \\
\text { the Standing } \\
\text { Committee }\end{array}$ & $\begin{array}{l}\text { November } \\
\text { 2014: } \\
\text { COP-11 of } \\
\text { the CMS }\end{array}$ \\
\hline
\end{tabular}




\begin{tabular}{|l|l|l|l|l|}
\hline & March 2011: & & September \\
fourth & 2013: \\
ITPGRFA & session of & fifth session \\
the & of the \\
Governing & & Governing \\
Body & Body & \\
\hline
\end{tabular}

Notes: The use of bold indicates the meetings where the SPB and its Aichi Biodiversity Targets were adopted by the other conventions. The use of regular font indicates meetings where the SPB and its targets were only discussed.

Table 1 illustrates two main aspects of the diffusion of the SPB and its Aichi Biodiversity Targets. First, as requested by the $\mathrm{CBD}$ in its initial decision, the reaction of the other related MEAs of the biodiversity cluster was immediate. Each of them took into consideration the outcomes of the CBD's COP-10 at their first meetings following this event. This process is not new, and the MEAs usually take into consideration the outcomes of major meetings. It is part of the synergistic effort that has been apparent among the biodiversity regime complex ${ }^{23}$ for several years. ${ }^{24}$ However, such a broad and systematic reaction to a decision adopted within the CBD seems to be a first, as illustrated in the following discussion. Second, for the three MEAs that incorporated the SPB in their normative corpus, the path that they followed was the same. Each of their COPs adopted amendments to their existing global strategies in order to contribute to the SPB. Clear linkages were established in order to confirm the role of the SPB as an overarching framework for biodiversity-related conventions. As such, taking into account that several other partnerships and programs had been created for the implementation of the SPB, ${ }^{25}$ it appears that one of the requirements of Decision X/2 of the CBD's COP-10 had been fulfilled: 'Cooperation will be enhanced with the programmes, funds and specialized agencies of the United Nations system as well as conventions and other multilateral and bilateral agencies, foundations and non-governmental organization. ${ }^{26}$ So,

\footnotetext{
${ }^{23}$ K Rausitalia and D Victor, The Regime Complex for Plan Genetic Resources 58 IO 277 at 279 (2004). The authors define a regime complex as being 'an array of partially overlapping and non-hierarchical institutions governing a particular issue-area.'

${ }^{24}$ UNEP-WCMC, supra note 11. Also, the numerous decisions taken by the different convention's decisional bodies on the subject of collaboration and partnerships provide an ample illustration of this tendency.

${ }^{25}$ For a more comprehensive review on this question, see Cooperation with Other Conventions, International Organizations and Stakeholder's Engagement, Including Business, Doc UNEP/CBD/COP/12/24 (2014).

${ }^{26}$ Strategic Plan for Biodiversity, supra note 6 at 12, para 24.
} 
having described the 'space time' of this diffusion, this article will now compare it to previous cases of diffusion in the biodiversity cluster.

\section{B. A Successful Diffusion}

In order to distinguish between the SPB diffusion and previous cases of diffusion in the biodiversity cluster, the following two examples can be used as points of reference. First, the CBD's 2002 strategic plan for biodiversity illustrates the uneasy cooperation among biodiversity-related conventions due to the conflicting relations between the different Secretariats and, as such, emphasizes the achievement of the current SPB in terms of collaboration. Second, the Addis Ababa Principles and Guidelines (AAPG) illustrate that, while the SPB's diffusion is not a 'first' in the literal sense, it may be the first time that we have witnessed such a widespread and systematic diffusion in the biodiversity cluster.

(i) The isolation of the 2002 strategic plan

Comparing the current diffusion to the fate of the 2002 strategic plan for the CBD sheds light on the substantial achievement made by the MEAs of the biodiversity cluster in collaborating closely on the establishment of a shared framework. Retrospectively, this failure of a broader diffusion can be understood by analysing the conceptualization of the previous plan and the actions undertaken for its diffusion. In 2002, the strategic plan established the notoriously unattained 2010 objective, and while the 2010 objective of the previous plan was omnipresent in the work of the biodiversity-related conventions, the strategic plan itself remained isolated. This is not surprising considering that whereas the SPB insisted on the need for collaboration among the biodiversity-related conventions, the previous plan was completely silent on this matter. The lack of widespread diffusion can therefore be interpreted as a probable consequence of this silence.

The reports on the implementation of the 2002 strategic plans that were made by several permanent bodies of the CBD help us to understand the extent to which the plan had an impact on the global governance of biodiversity. In 2004, at COP-7, a report was presented to the member states ${ }^{27}$ in which the endorsement of the strategy by the 2002 World Summit

\footnotetext{
${ }^{27}$ Follow-Up to World Summit on Sustainable Development, Multi-Year Programme of Work of the Conference of the Parties up to 2010: The Strategic Plan and Operations of the Convention, Doc UNEP/CBD/COP/7/20 (2004).
} 
on Sustainable Development was related. ${ }^{28}$ The SPB experienced a similar fate in 2012 when the Rio+20 declaration made an explicit mention of the current plan and its target. ${ }^{29}$ However, by comparing the two declarations, differences appear concerning the level of incorporation of the different strategic plans.

The Durban declaration only implicitly recognized the 2002 strategic plan by affirming the role of the CBD as 'the key instrument for the conservation and sustainable use of biological diversity and the fair and equitable sharing of benefits arising from use of genetic resources. ${ }^{30}$ It also called for the achievement of the CBD's objective and the reduction by 2010 of the current rate of loss of biological diversity. ${ }^{31}$ In other words, the 2002 strategic plan's 2010 objective was endorsed but not the plan as a whole. On the contrary, the Rio+20 declaration, entitled The Future We Want, explicitly mentions the newly adopted SPB and its Aichi Biodiversity Targets. ${ }^{32}$ The declaration clearly recalls 'the importance of implementing the Strategic Plan for Biodiversity 2011-2020, and achieving the Aichi Biodiversity Targets adopted at the Tenth Conference of the Parties to the Convention. ${ }^{33}$ If the Durban declaration gave the 2010 target widespread publicity in the field, it nevertheless appears that its impact on the activities of biodiversity-related conventions was not substantial. For example, the working documents of the CITES' COP-14 refer to the 2010 target as a general goal, but such reference does not seem to have had a measurable influence on the way that the convention reflects on its global strategy. ${ }^{34}$

Concerning the cooperation among MEAs on the implementation of the 2002 plan, there is little information in the official reports issued at the three CBD COPs that took place before the 2010 reformulation of the strategic framework. Moreover, the reports produced from the meetings of the Biodiversity Liaison Group (BLG) illustrate clearly the point of view of the biodiversity-related MEAs as their representatives openly expressed their stance vis-àvis the 2010 target. For instance, at the fifth meeting in 2006, Willem Wijnstekers, CITES' former secretary-general, recalled how the 2010 target was established without any prior consultation with the other MEAs and how it was not central in the implementation of CITES. ${ }^{35}$ This defiance towards the CBD and its former strategic plan is confirmed by

\footnotetext{
${ }^{28}$ Ibid, para 6.

${ }^{29}$ The Future We Want, Doc A/RES/66/288 (2012), para 197.

${ }^{30}$ Report of the World Summit on Sustainable Development, Doc A/CONF.199/20 (2002), para 44.

${ }^{31}$ Ibid.

${ }^{32}$ The Future We Want, supra note 29, para 197.

33 Ibid.

${ }^{34}$ CITES Strategic Vision 2008-2013, CoP14 Doc 11 (2007).

${ }^{35}$ Report of the Fifth Meeting of the Biodiversity Liaison Group (2006), para 11.
} 
interviews with the staff of the different Secretariats, thereby highlighting the problematic relationships existing within the cluster. ${ }^{36}$ This lack of cooperation and trust was eventually addressed by the actors of the biodiversity cluster when they were considering the revision of the 2002 plan. $^{37}$

All of these elements tend to support the idea that the elaboration and diffusion of the current strategic plan is mainly the result of a common understanding of what led to the failure of the 2002 plan in terms of cooperation. This aspect is fundamental since attaining the 2020 goals will not be possible without a common and coherent framework for all of the actors. Therefore, the conceptual pillars of the collaborative approach of the SPB were set by acknowledging, in consultation with others, what the previous plan had failed to initiate. ${ }^{38}$ In conclusion, the case of the SPB is completely opposite to the previous plan in terms of collaboration. However, this comparison only emphasizes the particularities of the SPB in the context of the former plan's isolation. In order to truly bring out its distinctive features as a diffusion case, parallels must be drawn with the other cases in the biodiversity cluster.

\section{(ii) AAPG}

The biodiversity cluster is characterized by several institutional linkages between MEAs. ${ }^{39}$ These linkages have been understood as being a method for managing fragmentation in global environmental governance. ${ }^{40}$ This relational structure is therefore highly favourable for the diffusion of concepts and/or norms among the different MEAs. This section of the article will analyse an example of a diffusion based on its first appearance in the CBD fora and its later incorporation in the normative corpus of other biodiversity-related conventions: the AAPG. On the general issue of synergies, a more comprehensive analysis of the different collaborations within the biodiversity cluster has been made by the UN Environment

\footnotetext{
${ }^{36}$ J Gomar, Environmental Policy Integration among Multilateral Environmental Agreements: The Case of Biodiversity, original contribution, International Environmental Agreements 1 (2014).

${ }^{37}$ Updating and Revision of the Strategic Plan, Doc UNEP/CBD/COP/9/14/Add.1 (2008), para 11: 'A number of Parties also stressed the importance of strengthening synergies among relevant conventions and international processes.'

${ }^{38}$ This topic is further elaborated in the following section on the role of the Secretariats.

${ }^{39}$ J Gomar, L Stringer, J Paavola, Regime Complexes and National Policy Coherence: Experience in the Biodiversity Cluster 20 Global Governance 119 (2014), see especially the figure at 123, which represents the different links.

${ }^{40} \mathrm{~K}$ Scott, International Environmental Governance: Managing Fragmentation through Institutional Connection 12 Melbourne J Intl L 177 (2011).
} 
Programme (UNEP) and the World Conservation Monitoring Centre (WCMC) in $2012^{41}$ and depicts accurately the achievements and remaining gaps in this field.

The AAPG were adopted at COP-7 to the CBD in 2004. ${ }^{42}$ Their aim was to provide a framework to ensure the sustainability of biodiversity uses. They were designed to be taken into account by 'governments, resource managers, indigenous and local communities, the private sector and other stakeholders' in order to 'ensure that their use of the components of biodiversity will not lead to the long-term decline of biological diversity. ${ }^{43}$ This framework was subsequently endorsed by other conventions and most notably by CITES.

A few months after the CBD's COP-7, the CITES' COP adopted a resolution on the sustainable use of biodiversity. ${ }^{44}$ Members made clear references to the CBD's decision on the matter and called for the implementation of the guidelines and further work on these guidelines by the relevant bodies. The working documents made available during COP-13 to CITES also emphasize the fact that the AAPG represent more of a cross-fertilization process, rather than a case of diffusion. Indeed, the principles were conceptualized by taking into account the 'non-detriment findings standards' of CITES. ${ }^{45}$ Moreover, this adoption of the AAPG was made in clear reference to the memorandum of understanding existing between CITES and the CBD (thus illustrating the fact that CITES had incorporated at least once in its resolutions a decision taken in another forum). ${ }^{46}$

Among the biodiversity cluster, CITES has been the only MEA to achieve this level of integration. The AAPG were discussed within the CMS but never expressly incorporated into a decision, and, as for the Ramsar Convention, the members had already relied on the concept of 'wise use' that was initially present in Articles 2 and 6 of the treaty. ${ }^{47}$ Finally, based on a review of the official documents available from the conventions, it appears that neither the World Heritage Convention nor the ITPGRFA took into consideration the AAPG during the meeting of their decision-making bodies.

\footnotetext{
${ }^{41}$ UNEP-WCMC, supra note 11.

${ }^{42}$ Sustainable Use (Article 10), Doc UNEP/CBD/COP/DEC/VII/12 (2004).

${ }^{43}$ Ibid. at 7.

${ }^{44}$ Sustainable Use of Biodiversity: Addis Ababa Principles and Guidelines, Resolution Conf. 13.2 (Rev. CoP14), (2004).

${ }^{45}$ Sustainable Use Principles and Guidelines, CoP13 Doc 12.1.2 (2004), para 2.

${ }^{46}$ Memorandum of Cooperation between the Secretariat of the Convention on International Trade in Endangered Species of Wild Fauna and Flora (Washington, DC, 1973) and the Secretariat of the Convention on Biological Diversity (Nairobi, 1992).

${ }^{47}$ As illustrated by the existence of several handbooks of the wise use of wetlands prepared by the Ramsar Convention's Secretariat. For a more detailed review on the relations between 'wise use' and the Addis Ababa Principles and Guidelines, see Ramsar Handbooks for the Wise Use of Wetlands (3rd edition, 2007), Handbook 1: A Conceptual Framework for the Wise Use of Wetlands, Appendix 1.
} 
Thus, the diffusion of the AAPG was significantly less broad than the current case of the SPB. However, this less broad diffusion did not mean that there was an absence of cooperation on the subject. For instance, the Secretariats of the biodiversity cluster, through the work undertaken within the BLG, worked on making the AAPG as accessible as possible for the diverse practitioners in charge of the implementation of the different MEAs. ${ }^{48}$ Although the principles did not undergo the same fate in terms of diffusion, they still were the subject of substantial cooperation between the conventions.

In conclusion, the diffusion of the SPB within the biodiversity cluster appears to be new in the sense that it can be noticed in all of the related MEAs and has led to substantive changes in the strategic plans of CITES, the CMS, and the Ramsar Convention. Compared to previous cases, such as the 2002 strategic plan and the AAPG, the SPB has clearly triggered significantly more intensive cooperation between conventions. This cooperation leads us to a second element that is important to the understanding of the SPB's diffusion: the actors behind it.

2. The Salient Role of the Secretariats: An Illustration of Their Influence within the Biodiversity Cluster

Underlining the cooperation between the conventions is an abstract notion. As understood from the second article of the Vienna Convention on the Law of Treaties (VCLT), a convention is simply an agreement concluded by states in written form and governed by international law. ${ }^{49}$ Strictly speaking, cooperation between conventions should then be analysed through the existing dispositions of their articles. However, none of the biodiversityrelated conventions (except for the ITPGRFA in relation to the CBD) have articles that specifically relate to cooperation between MEAs. As for Article 22 of the $\mathrm{CBD},{ }^{50}$ it only takes into account the possible conflicts of norms between the conventions. As a consequence, the framework for cooperation is set as a necessity dictated by the actors involved in the

\footnotetext{
${ }^{48}$ UNEP-WCMC, supra note 11 at 78.

${ }^{49}$ Vienna Convention on the Law of Treaties, 8 ILM 679 (1969) [VCLT].

${ }^{50}$ Article 22 : Relationship with Other International Conventions
}

1. The provisions of this Convention shall not affect the rights and obligations of any Contracting Party deriving from any existing international agreement, except where the exercise of those rights and obligations would cause a serious damage or threat to biological diversity.

2. Contracting Parties shall implement this Convention with respect to the marine environment consistently with the rights and obligations of States under the law of the sea. 
biodiversity regime complex — namely the members of the different MEAs, the respective bodies established by them, and the relevant non-state actors (NSA).

Relying on the official documents and archives that are available from the Earth Negotiation Bulletin, ${ }^{51}$ this article identifies the respective roles of these actors in the diffusion of the SPB and its Aichi Biodiversity Targets. By doing so, it aims to illustrate the miscellaneous types of influences that can be witnessed at an international level. In order to identify accurately the impact of the different actors, this section will take into account the negotiations that shaped the current SPB in its collaborative aspect and the subsequent discussions that promoted its diffusion. ${ }^{52}$

This analysis leads to one substantial finding: that the Secretariats of the MEAs have had a strong influence on the collaborative aspect of the SPB. However, before discussing this topic, it is important to stress here that the states and the NSA were not completely absent in the diffusion of the SPB. Indeed, the Secretariats have a necessarily restricted impact on the governance of their respective fields. Even if they have a high degree of influence and have been described as autonomous actors,${ }^{53}$ the shaping and adoption of regulations is a process in which other actors intervene. Yet the input from these other actors has been mainly influential in shaping the new strategic plan rather than in promoting its diffusion within other MEAs. For example, in regard to this specific issue, the International Union for the Conservation of Nature produced a document providing a useful analysis of the possible synergies between the other strategic plans and the SPB. ${ }^{54}$ In addition, during the different MEAs' COPs, states were mainly in favour of the incorporation of the SPB and its Aichi Biodiversity Targets in other strategic plans. The only exception to this tendency was during the CITES' COP-16 when the United States opposed the incorporation of the SPB. The United States is still not a party to the CBD, and its opposition can thus be understood to be a rejection of the CBD's influence over the biodiversity cluster. ${ }^{55}$ These important caveats aside, the Secretariats remain the key actors in this case of diffusion.

\footnotetext{
${ }^{51}$ The Earth Negotiation Bulletin is frequently used as an official report for multilateral negotiations in global environmental governance.

52 The documents accessed for this research only reflect a fraction of the realities that shape the relation between actors. Further research on this subject can and should be undertaken through interviews with the relevant participants of biodiversity-related conventions.

${ }^{53}$ F Biermman and B Siebenhüner, The Influence of International Bureaucracies in World Politic: Findings from the MANUS Research Program, in F Biermann and B Siebenhüner, Managers of Global Change the Influence of International Environmental Bureaucracies, 319 at 319 (2009).

${ }^{54}$ Report of the Fifth Meeting of the Chairs of the Scientific Advisory Bodies of the Biodiversity-related Conventions (CSAB) (2012), <http://www.cbd.int/doc/meetings/csab/csab-05/official/csab-05-report-en.pdf>.

${ }^{55}$ Gomar, supra note 36 at 13.
} 


\section{A. The Secretariats as Key Actors of the SPB's Diffusion}

Beginning with the efforts to update and revise the 2002 strategic plan, one can observe the critical influence that the Secretariats have had on the collaborative aspect of the SPB, particularly through the BLG. The BLG was established in 2004 at the CBD's COP-7 in order 'to enhance coherence and cooperation' in the implementation of the biodiversity-related conventions. ${ }^{56}$ It has since convened several meetings in order to work on the numerous aspects required for harmonization among the conventions. For example, it has sought to enhance cooperation in technical fields by establishing an informal group known as the Chairs of Scientific Advisory Bodies of Biodiversity-Related Conventions. ${ }^{57}$ This group has provided support for the harmonization of species nomenclature between CITES and the $\mathrm{CMS}^{58}$ and has constituted a forum for discussions on how to interact with the newly established International Platform on Biodiversity and Ecosystem Services (IPBES). ${ }^{59}$

Although the BLG has been criticized for not being able to produce concrete outcomes in the field of global biodiversity governance, ${ }^{60}$ it has nevertheless taken steps to increase its effectiveness. For instance, it established a 'modus operandi' to rationalize its activities. ${ }^{61}$ It also provided support for the elaboration by the CITES' Secretariat of an interactive CDROM on the AAPG that has been a useful tool for capacity building. ${ }^{62}$ Despite debates over its overall influence, it had definitely had a significant impact on the diffusion of the SPB among the biodiversity cluster.

The BLG is a venue where the Secretariats have been able to express concerns about the previous plan. As described earlier, the former secretary-general of CITES emphasized his concerns about the lack of collaboration in the adoption of the 2002 strategic plan as well as of the 2010 target. Even if the BLG's work was mainly focused on the achievement of this target, which was reflected in its reports since 2004, this initial flaw seems to have greatly hampered its collaborative approach. The different denominations of the strategic plans

\footnotetext{
${ }^{56}$ Cooperation with Other Conventions and International Conventions and Initiatives, Doc UNEP/CBD/COP/DEC/VII/26 (2004), para 2.

${ }^{57}$ Report of the Fifth Meeting of the Biodiversity Liaison Group, supra note 35, Item 3.

${ }^{58}$ Harmonization of Species Nomenclature and Taxonomy with Other Mutltilateral Environmental Agreements, Fourth Meeting of the Chairs of Scientific Advisory Bodies of the Biodiversity-Related Conventions (2011).

${ }^{59}$ For example, see Report of the Sixth Meeting of the Chairs of Scientific Advisory Bodies of the Biodiversityrelated Conventions (2013) at 2-3.

${ }^{60} \mathrm{R}$ Caddell, The Integration Of MEA: Lessons from the Biodiversity-Related Conventions 22 YIEL 37 at 59-62 (2011); A Johannsdottir et al, The Current Framework for International Governance of Biodiversity: Is It Doing More Harm Than Good? 19 RECIEL 139 at 144 (2010); Scott, supra note 40 at 201-3.

${ }^{61}$ Caddell, supra note 60 at 60.

${ }^{62}$ UNEP-WCMC, supra note 11 at 79.
} 
illustrate the paradigm shift in their conceptualization. 2002 was the year of the strategic plan for the CBD, whereas 2010 was the year of the strategic plan for biodiversity.

In September 2010, a month before the CBD's COP-10, a 'High Level retreat among Secretariats of Biodiversity-related conventions' was convened by the CBD's Secretariat. The members of the BLG and the members of the Joint Liaison Group (which is composed of members of the permanent bodies of the Rio conventions) discussed several important issues concerning the upcoming events among which the future SPB was to be addressed. ${ }^{63}$ The Secretariats recognized the relevance of the SPB as a framework for all biodiversity-related conventions, but it also stressed the fact that ultimately the choice of using the SPB was 'a matter for the governing bodies of those conventions to decide. ${ }^{64}$ This meeting further developed the discussion that occurred during the third meeting of the Working Group on the Review and Implementation of the CBD, in which the integration of the SPB among the biodiversity-related conventions was mentioned. ${ }^{65}$

These different meetings and the attention given to the Secretariats' inputs on the subject set the groundwork that was necessary to establish a feeling of ownership over the SPB within the different biodiversity-related conventions - the same feeling of ownership that was lacking in the previous plans. From here, it was possible for the Secretariats to act as brokers in their respective fields of action in order to include the SPB in the scope of their respective conventions.

The documents prepared by the different Secretariats for the different permanent bodies illustrate how central the Secretariats have been in the strategic guidance of their respective conventions. ${ }^{66}$ The reports that the Secretariats were in charge of drafting have influenced the outcomes of the meetings of the decisional bodies. The revisions of the strategic plans during the 2002-10 period took little notice of the CBD's 2002 strategic plan because of what could be seen as its previously described lack of ownership. For instance, within the CITES framework, the reports requested from the Secretariat on the revisions of the strategic vision never took into account the 2002 strategic plan, although both of the

\footnotetext{
${ }^{63}$ Summary of the First High Level Retreat among Secretariats of Biodiversity-Related Conventions (2010), para 5, <http://www.cbd.int/cooperation/doc/report-hlr-2010-09-01-en.pdf>. 
MEAs had ongoing partnerships and were collaborating within the BLG for the implementation of the 2010 target. $^{67}$

These elements are merely illustrations of the influence the Secretariats can have through the application of the articles that established them. Article 12 of CITES states that, among its different functions, the Secretariat shall invite the attention of the parties to any matter pertaining to the aims of the present convention. The CMS has the same reference to the role of its Secretariat, ${ }^{68}$ and while the Ramsar Convention's text only refers to a bureau that has less explicit influence, ${ }^{69}$ subsequent practice has led this organ to play much the same role. $^{70}$

In the case of the BLG, the CBD's Secretariat has found a venue where it is able to use its normative influence in an effective manner within the biodiversity cluster. ${ }^{71}$ As such, the collaborative approach set up within the BLG may be seen to be a success for the CBD's Secretariat, which has already been described as an overall 'well-functioning environmentalist international bureaucracy that has developed significant influence on international negotiations and cooperation as well as ... on scientific discourses. ${ }^{72}$ By promoting a framework based on common interests, rather than on a self-centred strategic plan, the CBD's Secretariat has managed to obtain the support of the biodiversity-related conventions (even if other important elements might have had an important influence on the behaviour of the other convention's bodies). ${ }^{73}$

However, the states have been the ones who have adopted the amendment to the different strategic visions. Would they have spontaneously proposed such an amendment if there had not been the input from the different Secretariats? Considering the fact that the national delegations for the meetings of biodiversity-related conventions are not necessarily coordinated prior to these events, ${ }^{74}$ it is difficult to know whether the states could have

\footnotetext{
${ }^{67}$ CITES Strategic Vision: 2008-2013, CoP14 Doc 11 (2007). In this document, the 2010 objective is referred to as a target set by the World Summit on Sustainable Development rather than as an outcome of the 2002 strategic plan.

${ }^{68}$ CMS, supra note 15, Article IX.

${ }^{69}$ Ramsar Convention, supra note 12 , Article 8

${ }^{70}$ See Ramsar Convention Secretariat, <http://www.ramsar.org/about/the-ramsar-convention-secretariat>. However, the Secretariats' influence is not always guaranteed. On this aspect, see S Bauer, Does Bureaucracy Really Matter? The Authority of Intergovernmental Treaty Secretariats in Global Environmental Politics 6 Global Environmental Politics 23 (2006).

${ }^{71} \mathrm{~F}$ Biermann et al., Studying the Influence of International Bureaucracies, in Biermann and Siebenhüner, supra note 53 at 48 . Normative influence is here described as the influence 'on global environmental governance through the creation, support and shaping of norm-building processes for issue-specific international cooperation.'

${ }^{72}$ B Siebenhüner, The Biodiversity Secretariat, in Biermann and Siebenhüner, supra note 53 at 285.

${ }^{73}$ This aspect is further developed in section 'A first Step towards Formal Access to GEF funding'.

${ }^{74}$ On this issue within the Latin American countries, see Gomar, Stringer, and Paavola, supra note 39.
} 
ensured by their own initiative the incorporation by the biodiversity-related conventions of the SPB and its Aichi Biodiversity Targets in their own strategic plans. Hence, the Secretariats of the biodiversity cluster appear to have had a measurable normative impact through their collaboration within the BLG. In short, the vast support of states for the diffusion of the SPB highlights the Secretariats' success in diffusing the SPB following the BLG consensus. However, a question remains: what have been the outcomes of this diffusion? What can be expected? Is it simply a political achievement with no legal repercussion or is there a potential legal impact of this phenomenon on the global governance of biodiversity and ecosystems?

III. THE EFFECTS OF THE DIFFUSION: A CONTRAST BETWEEN WEAK ISOLATED EFFECT AND STROND CUMULATIVE EFFECT

This section of the article will explore the different types of legal effects arising from the SPB's diffusion: first, the isolated effect of the incorporation of the SPB in other strategic plans MEAs' and, second, the cumulative effect of this diffusion on the biodiversity regime complex. The following analysis will illustrate that while isolated legal effects of the diffusion are weak, the phenomenon as a whole, associated with other decisions, can have concrete legal outcomes.

\section{The Weak Isolated Effect of the Diffusion}

On its own, the simple incorporation of the SPB and its Aichi Biodiversity Targets into other strategic plans has a relatively weak legal impact within the MEAs. This weakness is the result of adopting different strategic plans, their normativity, and their subsequent effects on the rights and obligations existing within the context of the MEAs. Indeed, the strategic plans, adopted through COP decisions, are a prime example of soft law in the field of global environmental governance. However, their influence on the positive obligations of states is only slight when considered as a single object.

\section{A. The Adoption of Strategic Plans}

Two main aspects must be highlighted concerning the adoption of the strategic plans within the Ramsar Convention, CITES, and the CMS. First, the current strategic plans are the result of similar developments for these three MEAs. During the 1990s, each of these conventions 
initiated review processes in order to assess their effectiveness after decades of existence. This process led to the adoption of strategic plans as means of properly orientating the subsequent actions of their members. These plans were then amended on a regular basis in order to reflect the new priorities of each of these conventions and were eventually harmonized through the incorporation of the SPB. The following table offers a short summary of this process.

Table 2: Simplified Chronology of the Use of Strategic Plans among the Ramsar Convention, CITES, and the CMS

\begin{tabular}{|l|l|l|l|}
\cline { 2 - 4 } \multicolumn{1}{c|}{} & First plans & $\begin{array}{l}\text { Revisions and } \\
\text { adjustments }\end{array}$ & $\begin{array}{l}\text { Incorporation of the } \\
\text { SPB }\end{array}$ \\
\hline Ramsar Convention & $\begin{array}{l}\text { COP-6, 1996, } \\
\text { Brisbane; } \\
\text { Resolution VI.14 }\end{array}$ & 2002 and 2008 \\
\hline CITES & $\begin{array}{l}\text { COP-11, 2000, } \\
\text { Giriri; } \\
\text { Annex 1 of Decision } \\
11.1^{77}\end{array}$ & 2004 and 2007 & 2013 \\
\hline CMS & $\begin{array}{l}\text { COP-4, 1994, } \\
\text { Nairobi; } \\
\text { Resolution 4.4 }\end{array}$ & 2011 & 2014 \\
\hline
\end{tabular}

As such, we can identify three distinct periods of governance in the biodiversity cluster. The first one took place when the three biodiversity-related conventions were implemented with no overarching framework in order to better channel the actions of the states. The second, which took place from the 1990s until the beginning of the 2000s,

\footnotetext{
${ }^{75}$ Most of the COP meetings led to discussions on the strategic plans, the years listed in this graph are those during which the COP added notable modifications to the strategic plans (eg, new time frame, new goals, or objectives).

${ }^{76}$ The Ramsar $25^{\text {th }}$ Anniversary Statement, the Strategic Plan 1997-2002, and the Bureau Work Programme 1997-1999, Resolution VI.14 (1996).

${ }^{77}$ See CITES, <http://www.cites.org/sites/default/files/eng/cop/11/other/Decisions.pdf>.

${ }^{78}$ Strategy for the Future Development of the Convention, Resolution 4.4 (1994).
} 
occurred when the conventions adopted strategic plans with the hopes of achieving greater coherence in their implementation. Finally, we are witnessing a major push towards greater harmonization among the biodiversity cluster by using the SPB as a common goal through its incorporation in other plans.

Second, the strategic plans were all adopted by the decisional bodies of the biodiversity-related conventions: the COPs. Several scholars have discussed the role and legal power of this atypical body of international law, but a definitive answer on this topic has yet to be established. ${ }^{79}$ It is therefore difficult to assert the exact legal nature of these strategic plans. Rather than trying to identify the exact nature of COPs and their decisions, Annecoos Wiersema argues that one should focus on the effect of the activity of the COPs by considering, on the one hand, the decisions that require the consent of the state before being bound by them (amendments, protocols, and so on) and, on the other hand, 'consensus-based activity' that requires the consent of the parties as a whole (and, therefore, has an effect on a state that has not formally expressed its consent). ${ }^{80}$ This latter category appears to be unsuited for the classical distinction of soft and hard law since the decisions issued by the COPs are necessarily dependant on the legal framework of the conventions into which they are entered. As such, they lack the autonomy of soft law since their existence is linked to another norm. However, they do not have the characteristics of hard law since they were not created through the treaty-making process nor identified as being customary. ${ }^{81}$

COP decisions, while being unfit for the theoretical distinctions that have been set up by international law scholars, still participate in orienting and 'thickening' the existing obligations of member states. ${ }^{82}$ However, this theory must be applied with a casuistic approach since COP decisions can be strictly symbolic as well as having a real legal impact on the obligations of the parties. As such, knowing the means of adoption of the strategic plans is of little help when trying to determine its legal impact.

\section{B. The Normativity of the Strategic Plans}

\footnotetext{
${ }^{79}$ R Churchill and G Ulfstein, Autonomous Institutional Arrangement In Multilateral Environmental Agreements: A Little Noticed Phenomenon In International Law 94 AJIL 623 (2000); J Brunée, COPing with Consent: law Making under Multilateral Environmental Agreements 15 Leiden J Intl L 1 (2002).

${ }^{80}$ A Wieserma, The New International Law-Makers? Conferences of the Parties to Multilateral Environmental Agreements, 31 Michigan J Intl L 231 (2009).

${ }^{81}$ Ibid.

${ }^{82}$ Ibid.
} 
According to Wieserma, even if the consensus-based activity of the COP cannot be analysed simply as soft law or hard law, a study of the wording and context of the different strategic plans can help in inferring their normativity. Decisions using different wordings (mandatory or optional) may have a different impact on the behaviour of the involved actors. By using the framework established by Kenneth Abbott and his colleagues in their article 'The Concept of Legalization,' a classification for the different strategic plans can be elaborated. ${ }^{83}$ The authors considered three different elements in legalization: obligation, ${ }^{84}$ precision, ${ }^{85}$ and delegation. ${ }^{86}$ Each of these elements can vary in strength, and the stronger they are the more the considered rule can be seen as 'hard law.' On the contrary, weak elements will be symptomatic of 'soft law.'

An overview of the SPB and the strategic plans in which it was subsequently incorporated indicates clearly that these plans all have the distinctive characteristics of soft law. They impose no binding obligation on states - they are only indications as to what would constitute the best outcomes for their actions. However, they are precise norms since they explain in detail what goals should be achieved. Even though they have no binding power, their precision is useful in the event that a state (or group of states) commits to achieving them. Lastly, with respect to delegation, the weakness of this aspect should be highlighted given that no jurisdiction has the power to assess their implementation.

Soft law has been widely discussed by scholars ${ }^{87}$ and is nowadays one of the most salient characteristics of international environmental law. However, in our case study, an important distinction can be made between the binding force of a norm and its legal effect. In the context of this article, legal effect is understood to be the changes induced by a norm on the rights and obligations of actors. ${ }^{88}$ So even if the strategic plans have all of the characteristics of soft law, it does not necessarily mean that their legal effect is weak.

\footnotetext{
${ }^{83}$ K Abbott et al., The Concept of Legalization 54 IO 401 (2000). For a critic of this article, see, in the same journal, M Finnemore and S Toope, Alternatives to 'Legalization': Richer Views of Law and Politics 55 IO 743 (2001).

${ }^{84}$ Abbott et al, supra note 83 at 401: 'Obligation means that states or other actors are bound by a rule or commitment or by a set of rules or commitment.'

${ }^{85} \mathrm{Ibid}$ : 'Precision means that rules unambiguously define the conduct they require, authorize, or proscribe.'

${ }^{86} \mathrm{Ibid}$ : 'Delegation means that third parties have been granted authority to implement, interpret, and apply the rules; to resolve disputes; and (possibly) to make further rules.'

${ }^{87}$ See, eg, P Weil, Towards Relative Normativity in International Law? 77 AJIL 413 (1983); C Chinkin, The Challenge of Soft Law: Development and Change in International Law 38 International and Comparative Law Quarterly 850 (1989).

${ }^{88}$ O Steffan, European Union Soft Law: New Developments Concerning the Divide between Legally Binding Force and Legal Effects 75 Modern Law Review 865 (2012).
} 
Therefore, as a final step in the study of the strategic plans, one must analyse their implementation.

\section{The Subsequent Implementation}

The recent adjustments to the strategic plans make it hard to assess with certainty the influence the incorporation of the SPB had on their implementation. However, by taking a closer look at the actions the previous strategic plans triggered in the context of the conventions' application, it is possible to measure the legal effects of these plans. The different strategic plans have had several different legal effects, although they were not significant. For instance, the CITES' plan may have had an effect on the reporting obligations of the members states. ${ }^{89}$ Even though the strategic vision does not specifically call for modifications of the reporting obligations of the state, the work of the CITES' Standing Committee, following the decisions taken by the COP, led to a modification of this procedural obligation.

The same influence on the reporting obligations can be perceived within the Ramsar Convention's framework, where the strategic plan calls for modification in the reporting obligation in order for the subsequent reports to present the activities undertaken for the realization of the different goals. These reporting obligations can be witnessed in the available reports submitted to the subsequent COP. For instance, the report of the Netherlands has a section detailing the decisions and actions taken in order to implement the strategic plan. ${ }^{90}$

All of these elements tend to support the hypothesis that, as such, the incorporation of a reference to the SPB in the strategic plans will have, at most, a limited legal effect on the different MEAs' regimes. However, the biodiversity cluster is now characterized by a growing cross-influence of its different elements. Weak isolated effects do not necessarily mean weak global effects. This disconnection between the sum and its parts is one of the fundamental aspects of 'regime complexes.' Since all of the different actors engage in an intricate legal and political architecture, the incorporation of the SPB as an overarching

\footnotetext{
${ }^{89}$ National Reports, Doc CoP 16 Doc 30 (Rev.1) (2013) at 5-6. Although not officially inscribed in the normative corpus of CITES, this document recalls the discussions on the reporting requirements concerning the CITES strategic vision.

${ }^{90}$ National Reports to Be Submitted to the Twelfth Meeting of the Conference of the Contracting Parties, Uruguay, (2015), Netherlands, <http://www.ramsar.org/sites/default/files/documents/2014/nationalreports/COP12/cop12_nr_netherlands.pdf >.
} 
reference in the different MEAs can be expected to have a significant influence on the governance system.

2. Cumulative Effects: An Example of Dynamics and Interrelations within the Biodiversity Cluster

As a whole, the diffusion of the SPB among the biodiversity cluster can be considered to be a supplementary means of management for the fragmentation of the biodiversity regime.

However, beyond these theoretical discussions on fragmentation, the diffusion of the SPB may very well have concrete practical repercussions, most notably concerning the access for conventions other than the CBD to GEF funding.

\section{A. A Significant Step towards Harmonization in the Biodiversity Cluster}

Interplay management has been referred to as 'conscious efforts by any relevant actor or groups of actors, in whatever form of forum, to address and improve institutional interaction and its effect. ${ }^{\prime 91}$ The diffusion of the SPB adds to several different interplay management tools used within the biodiversity cluster in order to cope with fragmentation that is understood as 'the emergence of specialized and (relatively) autonomous rules or rulecomplexes, legal institutions and spheres of legal practice. ${ }^{92}$ Yet, the SPB differs from the previous initiatives not only because of its holistic nature but also because of its potential impact on the interpretation of the biodiversity-related conventions.

(i) The SPB as a holistic framework for cooperation

The MEAs of the biodiversity cluster have engaged in a harmonization process for several decades. The attempt at harmonizing the relations between the conventions was particularly noticeable following the 1992 Earth Summit. With the adoption of the CBD as a global instrument for the conservation and sustainable use of biodiversity and ecosystems, other preexisting biodiversity-related conventions began to reflect on the necessary measures to be

\footnotetext{
${ }^{91} \mathrm{O}$ Stokke and S Oberthür, Introduction Institutional Interaction in Global Environmental Change, in O Stokke and S Oberthür (eds), Managing Institutional Complexity Regime Interplay and Global Environmental Change, 1 at 6 (2011).

${ }^{92}$ International Law Commission, Fragmentation of International Law: Difficulties Arising from the Diversification and Expansion of International Law, A/CN.4/L.682 (2006), para 8.
} 
taken to avoid duplication and overlapping but also to capture the valuable experience from other conventions. This approach can be witnessed in the first strategic plans of the biodiversity-related conventions, which all called on collaboration between the MEAs.

This cooperation and harmonization process has resulted mainly in two different types of instruments: memorandums and related joint work programs, on the one hand, and resolutions covering the specificities of cooperation, on the other hand. The use of memorandums varies from one convention to another. While CITES has a limited number of the agreements ${ }^{93}$ — within the biodiversity cluster as well as with relevant conventions and institutions - the CBD had concluded 157 agreements with different partners by $2010 .{ }^{94}$ The legal nature of these agreements has yet to be formally determined, ${ }^{95}$ and, whatever it might be, the memorandums typically only concern the relationship between institutions and do not concern directly the obligations of the MEA parties. Nevertheless, their use is widespread within the biodiversity cluster, and practically all of the conventions are institutionally linked to one another via these instruments.

Alternatively, joint work programs are focused on very specific actions. Moreover, even though they are set within the framework of the memorandums established between the Secretariats, they can also call for actions from the member states. The joint work program established between the CMS and the CBD for the $2002-05$ period $^{96}$ has a very detailed set of actions to be undertaken by the different actors of both regimes, be they institutions or parties. Conversely, the joint work program between the CMS and the Ramsar Convention only concerns the MEAs' Secretariats. ${ }^{97}$ It seems that there is no general architecture for joint work programs, but they tend to focus on specific themes, contrasting with the broader, but strictly institutional, cooperation established by the memorandums. Memorandums and joint programs appear as supplementary elements that stress the role played by the Secretariat in the global governance of biodiversity and ecosystems.

In addition, MEAs have unilateral approaches to cooperation. The COPs have adopted several decisions establishing the framework for collaboration. These decisions can concern specific MEAs or the whole set of relevant treaties. For instance, the COPs of the CMS and the Ramsar Convention have adopted resolutions concerning cooperation and synergies with

\footnotetext{
${ }^{93}$ CITES, <http://www.cites.org/eng/disc/coop.php>.

${ }^{94}$ Scott, supra note 40 at 192.

${ }^{95}$ Ibid.

${ }^{96}$ CBD/CMS Joint Work Programme (2002-2005), Doc UNEP/CMS/Inf.7.13 (2002).

${ }^{97}$ Joint Work Plan 2012-2014 Secretariats of the Ramsar Convention and the Convention on Migratory Species (2012), <http://www.ramsar.org/sites/default/files/documents/pdf/moc/Ramsar-CMS_JWP2012-2014.pdf>.
} 
other relevant bodies on several occasions. However, CITES has only recently adopted a resolution on the broader aspect of collaboration with other relevant conventions, ${ }^{98}$ which coexists with two resolutions concerning the relationship with the $\mathrm{CMS}^{99}$ and the CBD. ${ }^{100}$ Jose Gomar, Lindsay Stringer, and Jouni Paavola have provided a very useful graph representing the architecture of memorandums and joint programs existing within the biodiversity cluster (see Figure 1). ${ }^{101}$ The following diagram is a simplified reproduction of their original contribution.

Figure 1: Institutional Cooperation Web in the Biodiversity Cluster

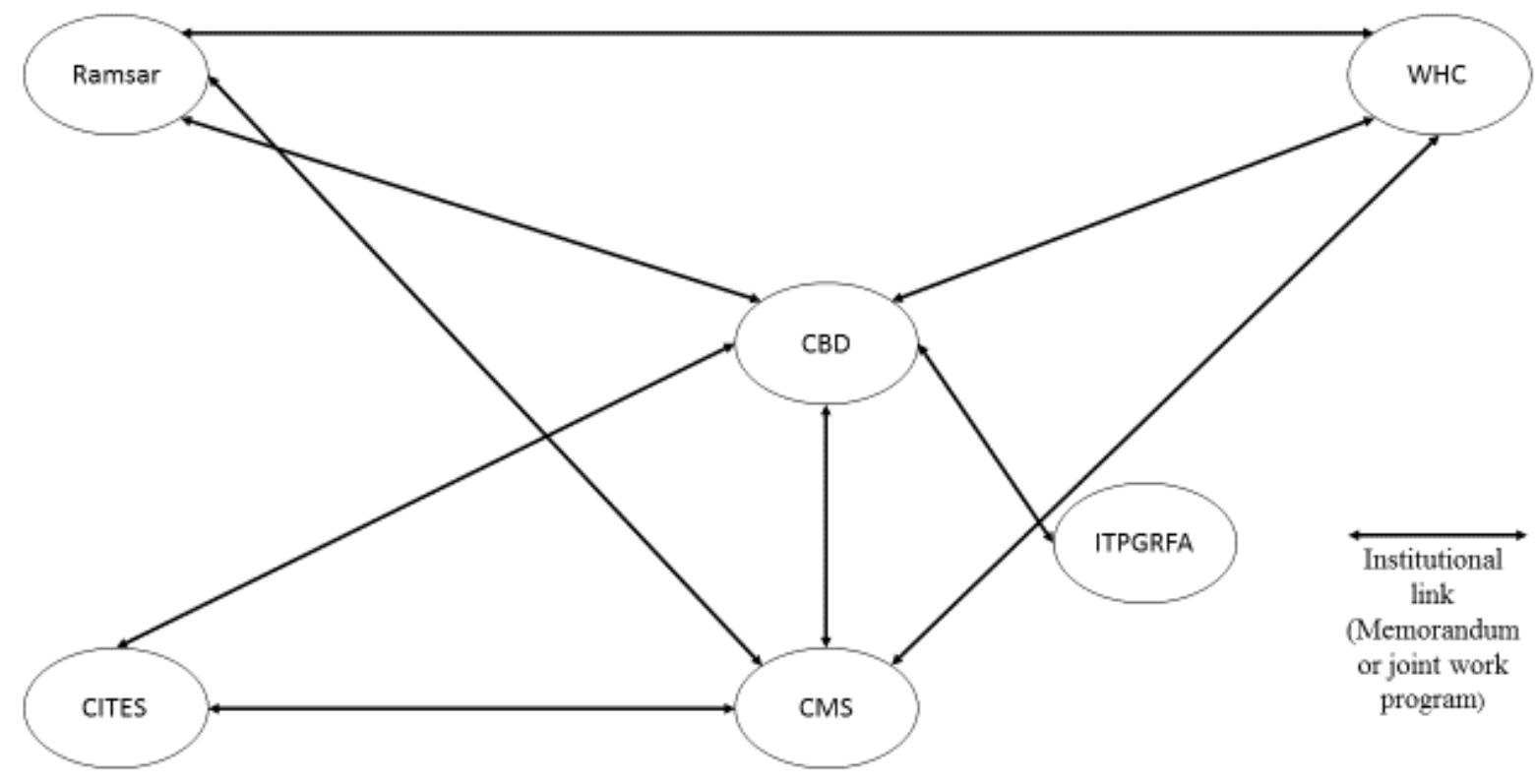

Source: Simplified version of the graph in J. Gomar, L. Stringer, J. Paavola, Regime Complexes and National Policy Coherence: Experience in the Biodiversity Cluster 20 Global Governance 119 (2014)

This 'web' clearly emphasizes both the centrality of the CBD within the biodiversity cluster and the numerous collaboration initiatives in the cluster. Thus, it raises the question of knowing what the added value of the SPB diffusion is. Will it—can it — have a significant

\footnotetext{
${ }^{98}$ Cooperation of CITES with Other Biodiversity-related Conventions, Resolution Conf. 16.4 (2013).

${ }^{99}$ Cooperation with the Convention on the Conservation of Migratory Species of Wild Animals (CMS), Resolution Conf. 13.3 (2004).

${ }^{100}$ Cooperation and Synergy with the Convention on Biological Diversity, Resolution Conf. 10.4 (Rev. CoP14) (1997).

${ }^{101}$ Gomar, Stringer, and Paavola, supra note 39.
} 
impact on collaboration in the biodiversity cluster? As a general framework, for actions to be undertaken by all relevant actors the SPB must appear to be a holistic and indirect approach for collaboration. By mainstreaming all activities in order for them to meet a clear and preestablished set of goals, the diffusion of the SPB prevents conflicting actions. As such, this diffusion is complementary to the other means of synergies that aim to prevent the duplication of actions. The accumulation of these management means is a significant step towards optimum synergy within the cluster. As stated earlier in this article, each cluster is unique, and at this point comparing the 'biodiversity cluster' to the 'chemical cluster'-which is admittedly a remarkable example of integration among different MEAs - is not necessarily relevant. Indeed, the Secretariats of the biodiversity cluster-which appear to be the most influential architects for synergy — have underlined the fact that, considering the history of the different MEAs, this example could not be reiterated with the biodiversity-related conventions. ${ }^{102}$

(ii) The SPB as a common standard for interpretation

While the SPB appears to be a useful complementary and overarching tool for synergies between conventions, it may also have an influence on the interpretation of the MEAs that have incorporated it in their strategic plans. The widespread diffusion of the SPB and its targets, either in other strategic plans or in decisions taking note of its existence, can be an important element in the interpretation of the biodiversity-related conventions. The different methods for treaty interpretation are described in Articles 31-33 of the VCLT ${ }^{103}$ and have been recognized as reflecting international custom on this issue. ${ }^{104}$ In the present case, Article 31 is the most relevant to understanding the potential effect of the SPB diffusion.

On the question of interpretation, the existing literature in legal research is abundant. Several conceptual approaches exist and, depending on which one is followed, the diffusion of the SPB and its targets may have an influence on the general interpretation of treaties in the biodiversity cluster. First, with respect to the object and purpose of the biodiversity-related conventions, the fact that the SPB is now a generally accepted framework for all of the studied treaties indicates that they now share a common purpose. However, this general

\footnotetext{
102 Eighth Meeting of the BLG (13 February 2013), paras 3, 29.

${ }^{103}$ VCLT, supra note 49.

104 The International Court of Justice has reiterated this fact on several occasions, eg, LaGrand (Germany / United State of America), 27 June 2001, [2001] ICJ Rep 466, para 99.
} 
assertion is not as simple when one considers the doctrine on the objects and purposes of treaties. On this topic, there is a debate between the French school of thought and other schools of thought. ${ }^{105}$ The French doctrine operates a distinction between the object and the purpose. Simply put, the object of a treaty is 'what' the treaty does. The purpose is 'why' it does it. As stated by Mustafa Kamil Yasseenn in his lesson on the interpretation of treaties at the Hague Academy, 'the object is what the parties did, what they stated, the rights and obligations resulting from this, whereas the purpose is what the parties aimed at achieving., 106

This distinction is best explained with a concrete example. The object of CITES is trade regulation in a specific domain: wild species. Its purpose is the reduction of trade-related pressure on global biodiversity. However this statement is open to discussion since most of the time there is no clear proclamation on this distinction within the treaty text. This leads to a circularity problem where in order to identify the object and purpose of the treaty one must first interpret it. But, then, the interpretation must be done in accordance with its object and purpose. ${ }^{107}$ Isabelle Buffard and Karl Zemanek suggest that in order to escape this vicious circle, the interpreter must first establish a prima facie object and purpose and then proceed to interpret the treaty. ${ }^{108}$ This leads to a back-and-forth movement between the text and its prima facie objective and purpose, resulting in a constant refinement of both elements. ${ }^{109}$ In some cases, conventions contain dispositions clearly stating their objectives or purposes. For instance, the ITPGRFA's first article states the objectives of the convention. This is also the case for the Minamata Convention on Mercury. ${ }^{110}$

The fact that the biodiversity-related conventions have now 'adopted' the SPB and its targets, and that three of them have incorporated it in their own strategic plans, tends to indicate that while their objects remain the same their purposes are undergoing a harmonization process. While the initial obligations remain, they are now implemented in order to achieve a common purpose. Moreover, this theoretical distinction allows us to

\footnotetext{
105 I Buffard and K Zemanek, The Object and Purpose of a Treaty: An Enigma 3 Austrian Revi Intl Eur L 331 (1998).

${ }^{106}$ M Yasseen, L'interprétation des traités d'après la Convention de Vienne sur le Droit des Traités, 151 RCADI at 55 (1976) (free translation, in French): 'L'objet du traité est ce que les parties ont fait, les normes qu'elles ont énoncées, les droits et les obligations qui en découlent, tandis que le but du traité est ce que les parties ont voulu atteindre.'

${ }^{107}$ Buffard and Zemanek, supra note 106 at 333.

108 Ibid.

${ }^{109}$ Ibid.

${ }^{110}$ Minamata Convention on Mercury (2013), <https://treaties.un.org/doc/Treaties/2013/10/20131010\%201116\%20AM/CTC-XXVII-17.pdf> (english version on 49).
} 
operate a distinction between the effectiveness of the treaties and their efficacy. ${ }^{111}$ In this particular context, effectiveness is whether or not the object of the treaty-its obligations - is implemented. Efficacy is achieved if the obligations tend to the fulfilment of the purpose. Therefore, using the distinction between object and purpose - effectiveness and efficacyallows us to realize a legal assessment of a treaty through interpretation. By identifying the object and the purpose, one can then assess if the obligations are really implemented and, second, if they really tend to fulfil the purpose of the conventions. With the SPB as a common framework for the biodiversity-related conventions, the reviewing of these instruments is now far more coherent.

In addition, recognizing the SPB and its targets as major elements of the purpose of the biodiversity-related conventions would have broad legal consequences for states wishing to join these conventions. It would limit the possible scope of any reservation they would seek to hold against these treaties, as Article 19(c) of the VCLT prohibits reservations that are incompatible with the object or purpose of the treaty. Another obligation that would be potentially influenced by the SPB as a shared purpose would be the obligation not to defeat the object and purpose of a treaty prior to its entry in force (Article 18 of the VCLT). This obligation would also influence any bilateral agreement between parties of the biodiversityrelated conventions in order to modify them (Article 41 of the VCLT). Finally, actions clearly going against the SPB could be considered to be material breach of the conventions and thus result in the termination of the treaty (Article 60 of the VCLT). Thus, in theory, seeing the SPB as a common purpose has substantial legal impacts on the biodiversity regime. However, as often happens in the field of international environmental law, legal theory is dwarfed by political realities.

As useful as this distinction between object and purpose might be in this context, doctrine and practice on this issue tend to move in a different way. Authors often criticize this distinction because of its origin. They argue that, although this distinction might be relevant at a national level, it has no legitimate justification at the international level. ${ }^{112}$ Moreover,

\footnotetext{
111 This distinction draws on the differentiation between 'effectivité' (effectiveness) and 'efficacité' (efficacy) that exists in the French legal doctrine. See S Maljean-Dubois and V Richard, Mécanismes Internationaux de suivi et de mise en cuvre des conventions internationales de protection de l'environnement 9 IDDRI 13 (2009). If a regime is both 'effectif' and 'efficace,' it will then be considered as being effective, the term being understood here in its common English doctrine definition (see, eg, A Hasenclever et al., Interests, Power, Knowledge: The Study of International Regimes 40 Mershon Intl Studies Rev 177 at 178 (1996): 'First, a regime is effective to the extent that its members abide by its norms and rules. Second, a regime is effective to the extent that it achieves the objectives or purposes for which it was intended.'

${ }^{112}$ D Jonas and T Saunders, The Object and Purpose of a Treaty: Three Interpretative Methods 49 Vanderbilt J Transntl L 565 at 580 (2010).
} 
international jurisdictions have, on at least one occasion, dismissed this distinction. In 2004, in an arbitration between France and the Netherlands, ${ }^{113}$ the court stated that the elements of Article 31 of the VCLT should be perceived as a whole, rather than as distinct items. ${ }^{114}$ Should this distinction between object and purpose be abandoned in the present scenario, the diffusion of the SPB and its objective would at least have an impact on the context for interpretation.

However, the difficulty is to identify the nature of the SPB and the strategic plans and incorporate it in the different categories constituting 'the context,' according to the VCLT. If we consider the SPB and the other strategic plans incorporating it as acts of COPs, it becomes unclear in which category they can fall. Acts of COPs are not related to the conclusion of the treaty, therefore they are not within the scope of Article 31.2. They can be seen, however, as a 'subsequent agreement between the parties regarding the interpretation of the treaty or the application of its provisions' (Article 31.3.a). In this case, the problem lies in the definition of an agreement according to the VCLT. If this term is understood as a synonym of 'treaty,' then acts of a COP do not fall into this category. Conversely, a broader understanding of the term based on the consent of the parties allows us to consider COP activity as agreements. Should acts of COPs be considered to be different from agreements, they would nevertheless represent 'subsequent practice in the application of the treaty which establishes the agreement of the parties regarding its interpretation' (Article 31.3.b). This highlights the fact that determining the legal nature of COP decisions would not have an impact on the establishment of the context for interpretation since they would necessarily fall within the scope of Article 31.3.a or 31.3.b.

Finally, considering the 'relevant rules of international law applicable in the relations between the parties' (Article 31.3.c), it raises the issue of the relevance of the classical sources of international law. According to this approach, COP activity does not fall into any of the sources of international law. Yet it has been demonstrated that it can have concrete legal effects. As discussed earlier, there is currently no definitive answer to the legal nature of COP activity. However, this article chooses to consider COP activity as the 'relevant rules of international law' based on the approach developed by Wiersema. ${ }^{115}$ Indeed, although COP decisions lack in autonomy, they still have concrete legal repercussions and should be

\footnotetext{
${ }^{113}$ Apurement des comptes entres les Pays-Bas et la France (Netherlands /France), Arbitral Sentence, 12 March 2004, [2004] PCA 1 para 62.

114 Ibid.

115 Wieserma, supra note 80.
} 
considered, de facto, as relevant. Therefore, the SPB, as a whole and through its incorporation within other strategic plans, is an essential part of the context for the interpretation of the biodiversity-related conventions.

However, who is the interpreter? Most of the literature focuses on the role of the judge in the context of conflictual interpretation. Yet this focus has little significance in the context of the biodiversity cluster since the intervention of a judge as a means of resolving disputes is highly unlikely. These MEAs usually establish their own mechanisms in order to monitor the implementation of their obligations, and these mechanisms differ from the judicial process through which a judge or an arbitrator will interpret a treaty. As such, the previous analyses will surely remain theoretical in view of the fact that none of them is likely to be validated or rejected through conflict resolution. Moreover, the practice of states concerning the interpretation of their obligations in the biodiversity cluster is set outside of the VCLT (as demonstrated by the various decisions adopted by the COPs on the interpretation of the wording or the article of the treaties).

This 'free' interpretation of the conventions by the parties through acts of COPs highlights the fact that the interpretation rules set by the VCLT are inherently 'conflictual.,116 When set in a cooperative environment, state members of the biodiversity cluster will choose to interpret their obligations based on various types of considerations - for instance, technical and scientific ones. Even when legal considerations are at stake, such as defining exactly what the amendment procedure of a treaty should be, states do not make reference to the VCLT. ${ }^{117}$ This is not surprising, and commentators have highlighted this aspect on numerous occasions: 'The international law of treaty interpretation is based on the perspective of an objective third party, such as a court, seeking to interpret an agreement after it has been negotiated. ${ }^{118}$ Therefore, even though the theoretical impact of the SPB can be significant, without the intervention of a third party there can only be speculation. Nevertheless, through the accumulation of decisions concerning the SPB within the biodiversity cluster, the practical impact of the SPB's diffusion can be witnessed in some circumstances-for example, in relation to Global Environmental Facility (GEF) funding, which is described in the following section.

\footnotetext{
${ }^{116}$ K Vandevelde, Treaty Interpretation from a Negotiator's Perspective 21 Vanderbilt J Transntl L 281 at 294 (1988).

${ }^{117}$ See Interpretation of Article 10 bis Paragraph 6 of the Convention, Ramsar Resolution 4.1 (1990); Interpretation of Article XVII, CITES Resolution Conf. 4.21 (1983), para 3.

${ }^{118}$ Vandevelde, supra note 117 at 282.
} 


\section{B. A First Step towards Formal Access to GEF Funding}

The GEF was established in 1991 as a World Bank program in order to assist projects aimed at the promotion of sustainable development and the protection of the environment. ${ }^{119}$ The rationale of this program was to provide financial help so as to transform the national benefits of a project into global environmental benefits. This program was later restructured in 1994 following the Rio Earth Summit and became a permanent institution functioning as the financial mechanism for several conventions: the CBD, the UN Framework Convention on Climate Change, ${ }^{120}$ the United Nations Convention to Combat Desertification in those Countries Experiencing Serious Drought and/or Desertification, Particularly in Africa, ${ }^{121}$ the Stockholm Convention on Persistent Organic Pollutants, ${ }^{122}$ and the Minamata Convention on Mercury. Each of these convention texts comprises an article concerning the GEF and its role. In 2014, 183 states were members of the GEF (including the United States).

The GEF trust fund is replenished every four years. Recently, the GEF underwent its sixth replenishment set over the 2014-18 period. The discussions leading to the replenishment process are crucial as they shape the financing priorities of the future fund. These discussions involve the contributing states and frame the development of different strategies that are 'guidance from the relevant conventions for which the GEF serves as an interim financial mechanism. ${ }^{123}$ As such, the GEF has established approximately a dozen strategies reflecting the objectives and purposes of the conventions for which it plays the role of financial mechanism.

In this context, the diffusion of the SPB - most notably the incorporation of its targets into other strategic plans - is a key element for access to GEF funding. Indeed, in September 2013, the BLG convened a meeting, ${ }^{124}$ upon the request of the GEF Secretariat. This request was made following the forty-first meeting of the GEF Council, which took into consideration the request of the CITES' Secretariat to access GEF financing for the implementation of the convention. ${ }^{125}$ During this meeting, clear statements were made regarding the role of the SPB

\footnotetext{
${ }^{119} \mathrm{GEF},<$ http://www.thegef.org/>.

${ }^{120}$ United Nations Framework Convention on Climate Change, 1771 UNTS 107 (1992).

${ }^{121}$ United Nations Convention to Combat Desertification in those Countries Experiencing Serious Drought and/or Desertification, Particularly in Africa, 1954 UNTS 3 (1994).

122 Stockholm Convention on Persistent Organic Pollutants, 2256 UNTS 119 (2001).

123 GEF strategies, <http://www.thegef.org/gef/strategies>.

${ }^{124}$ Report of the Meeting of the Liaison Group of the Biodiversity-Related Conventions (9 September 2013), <http://www.cbd.int/cooperation/doc/blg-2013-09-09-en.pdf>.

${ }^{125}$ Highlights of the Council's Discussions GEF Council Meeting (8-11 November 2011), para 3, $<$ http://www.thegef.org/gef/sites/thegef.org/files/documents/Highlights_Revised_11-18-11.pdf >.
} 
as an entry point to GEF funding. For instance, it was clearly stated that 'additional funding for activities of biodiversity-related conventions other than CBD may be obtained from the GEF if the activities contribute to the achievement of the Strategic Plan for Biodiversity 20112020 and its Aichi targets.' Moreover, the intention of the conventions' Secretariat were transparent throughout the meeting report. Sentences such as the following highlight the objective of the Secretariats regarding the GEF: 'In emphasizing the importance of using better programmatic synergies among the biodiversity-related conventions as a means for obtaining better access to GEF funds for those conventions for which the GEF is not, or not $y e t,{ }^{126}$ the financial mechanism., ${ }^{127}$

Among the bodies working on this topic, the CITES' Secretariat appears to be the most proactive. Indeed, discussions on the possibility of accessing GEF funding have been ongoing within CITES since the sixty-first meeting of its Standing Committee in 2011. At this meeting, the Secretariat presented its findings following the 2010 decision requesting it to 'investigate possible ways to establish the means to secure funding to support the provision of technical assistance to CITES Parties in relation to regulating wildlife trade.' ${ }^{128}$ The GEF was then presented as a potential financial mechanism for CITES. The Secretariat continued its work on this matter and presented a document at COP-16 inviting the member states to accept the GEF as a financial mechanism for CITES. ${ }^{129}$ States were mainly in favour of this proposition ${ }^{130}$ but postponed its adoption until the next COP in order for the Secretariat to further elaborate on this topic. ${ }^{131}$

Between the sixty-first meeting to the Standing Committee and COP-16, several conferences gave momentum to the CITES' Secretariat's objective of finding a means to access GEF funding. In 2012, the CBD held its COP-11 in Hyderabad where the GEF was instructed to include the SPB and its targets in the strategy concerning biodiversity. ${ }^{132}$ This diffusion of the SPB in the GEF framework was a seminal step towards a broader financing for conventions having adopted the SPB within their own strategic plan. Even though the GEF was not adopted as a financial mechanism for CITES during its last COP, all of the elements seem to be concurring for this aim at the next COP in 2016. The last meeting of the CITES'

\footnotetext{
${ }^{126}$ Emphasis added.

${ }^{127}$ Report of the Meeting of the Liaison Group of the Biodiversity-Related Conventions (9 September 2013), para 5 .

${ }_{128}$ Access to Finance, including GEF Funding, SC61 Doc 16 (2011).

${ }^{129}$ Access to Global Environment Facility Funding, Doc CoP16 Doc 8.4 (2013)

130 21(82) Earth Negotiations Bulletin 4.

${ }^{131}$ Access to Global Environment Facility Funding, Decision 16.2 (2013).

${ }^{132}$ Report on the Sixth Replenishment of the GEF Trust Fund, Doc GEF/A.5/07/Rev.01 (2014), paras 6-7.
} 
Standing Committee, which was held in July 2014, offers a clear illustration of the importance of the SPB diffusion in this context. The Secretariat, in its report to the Standing Committee, stated that ' $[b] y$ including reference to the Strategic Plan for Biodiversity and Aichi Targets in the CITES Strategic Vision 2008-2023, the Conference of the Parties has opened up the GEF biodiversity window to species-specific issues that contribute towards achieving relevant Aichi Targets, especially but not exclusively Target 12.'

However, the outcome of these discussions is still uncertain. It was noted during that meeting that the process for the GEF to formally become a financial mechanism for CITES had not yet started. ${ }^{133}$ How can the GEF become a formal financial mechanism considering the fact that, for the conventions relying on the GEF, its status is inscribed within the text of the conventions? Two hypotheses are possible. The first one would be to 'simply' amend the text of CITES by adding dispositions related to the GEF. However, the amendment procedure is subject to the very strict conditions of Article XVII of CITES, and CITES has only been amended twice and the procedure leading to the entry into force of the amendments is extremely lengthy (thirty years for the Gaborone Amendment). In addition to being slow, the outcome of the procedure is also unpredictable since the two-thirds requirement can lock the process into a stalemate for several years.

The second hypothesis would be to construct a 'legal scheme' based on institutional partnerships and the diffusion of the SPB. This method could bypass the obstacles inherent in the amendment procedure. For instance, a memorandum of understanding could be concluded between the GEF and CITES. The financing of activities implementing CITES could then be possible, on the condition that those activities contribute to the achievement of the SPB and its Aichi Biodiversity Targets. In a way, on a practical level, the results would be the same as if the treaty was amended. The only difference would be a formal dependence on the SPB and its targets as an imperative condition that would need to be fulfilled in order to access GEF funding. If this hypothesis were to be applied, it would then be a situation where the accumulation and interplay of 'soft' measures such as memorandums and the diffusion of strategic plans within a broader context would lead to practical effects equivalent to an amendment.

This puts into perspective the usual distinction in international law between soft law and hard law and may also contradict Prosper Weil's assertion that 'the proliferation of soft norms ... does not help strengthen the international normative system. ${ }^{, 134}$ Currently, this

\footnotetext{
133 21(84) Earth Negotiations Bulletin 5.

${ }^{134}$ Weil, supra note 87 at 415.
} 
proliferation of soft norms appears to be a mean of reinforcing the existing 'hard law.' This highlights the relevance of the distinction between object and purpose, effectiveness and efficacy. By accessing GEF funding, the members of CITES would have the means to insure that the implementation of CITES is coherent with its purpose. Consequently, this would increase the efficacy of the convention.

This distinction between effectiveness and efficacy is of great importance when considering international environmental law (or any laws regarding the environment). If a convention is implemented but does not succeed in attaining its purpose, can it be considered to be a success? Must a norm only be evaluated on its strict implementation rather than on its concrete outcomes regarding the reason for its adoption? Furthermore, what is the point of a rule if its recipient does not have the possibility of implementing it? In the case of CITES, the dispositions of the treaty are implemented since each member has set up management and scientific authorities who are in charge of trade regulation, but the pressure on biodiversity caused by international trade is still not decreasing. ${ }^{135}$ In this case, the simple implementation of norms is not sufficient since the object of the treaty - the regulation of international trade in endangered wild fauna and flora - has been transcribed into norms, but its purpose - the elimination of the pressure caused by this international trade on biodiversity-is still not being met. This is the direct result of the numerous obstacles that exist at a local level in implementing the convention. Even if states have met the formal requirements of the treaty, they still must face very concrete issues such as training competent customs officials or scientists specialized in taxonomy, regulating illegal trade, and mitigating corruption. Here, the financial assistance of the GEF could have a significant impact, as it had on the eastern countries that relied on its assistance in order to apply the Montreal Protocol on Substances That Deplete the Ozone Layer. ${ }^{136}$

As discussed earlier in this article, we believe that object and purpose, effectiveness and efficacy, are relevant indicators when analysing the success or failure of a legal system. For instance, quotas adopted in order to prevent the depletion of fish stocks can be effective. However, if these quotas are not adequate regarding the biological characteristics of the stocks, then they will lack in efficacy since they do not prevent depletion. In this sense, there can be no practical efficacy without effectiveness, but effectiveness alone does not necessarily

\footnotetext{
$135 \mathrm{~J}$ Beurier, Droit international de l'environnement (4th edition, 2010) at 335.

${ }^{136}$ GEF, GEF Focal Area: Ozone Layer Depletion (2009) at 1: 'Technical and financial support to countries with economies in transition in Central and Eastern Europe and the former Soviet Union has helped these countries reduce their consumption of ozone-depleting substances by 99 percent.'
} 
lead to efficacy. GEF assistance can be seen as a concrete means of insuring both effectiveness and efficacy, depending on the obstacles faced by the parties, and, therefore, in the case of the CITES, of strengthening its normative system.

On the question of GEF funding, the bodies of the CMS and the Ramsar Convention have been less expressive than the CITES' Secretariat. The member states of the CMS called for an enhanced engagement with the GEF in $2011^{137}$ and requested the convention's Secretariat to engage with the GEF on the opportunities of funding for activities undertaken by the states relevant to the implementation of the CMS. The question was identified as a medium priority topic during the last COP in November 2014. ${ }^{138}$ In 2012 in Bucharest, COP11 to the Ramsar Convention issued a resolution on partnerships and synergies with MEAs and other institutions ${ }^{139}$ that only briefly evoked the GEF. ${ }^{140}$ As for CITES and the CMS, the Secretariat was also requested to develop further relationships with funding organizations. However, it does not seem that this topic was thoroughly discussed during the last meeting of the Ramsar Convention's Standing Committee in October 2014.

Should the CITES experience with the GEF prove successful, it may be a strong incentive for reiterating the process in other fora. There seems to be no major obstacle for this link to be formally made since, as the GEF secretary recalled during the BLG meeting, the GEF already has supported indirectly numerous activities from other conventions. Moreover, since the BLG has proven to be an efficient catalyst for cooperation, it could prove itself useful once more by serving as an exchange platform for Secretariats. CITES' next COP will be decisive on this issue, and, should the GEF become a financial mechanism for the convention through the means of 'unconventional' measures, it would provide definitive proof that international environmental law has overthrown the classic conceptions of international law. This would also be a first step towards a broader recognition of the GEF in the biodiversity cluster as this institution has been described as lacking visibility among the actors of global governance. ${ }^{141}$

Figure 2 illustrates how access to GEF funding is the result of an elaborate interplay of 'soft' norms leading to a very practical and measurable outcome, thereby highlighting the difference between the binding aspect of a norm and its legal effect.

\footnotetext{
${ }^{137}$ Enhancing Engagement with the Global Environment Facility, Doc UNEP/CMS/Resolution 10.25 (2011).

${ }^{138}$ Draft Resolution Financial and Administrative Matters, Doc UNEP/CMS/COP11/CRP34 (2014) at 23.

${ }^{139}$ Partnerships and Synergies with Multilateral Environmental Agreements and Other Institutions, Resolution XI.6 (2012).

${ }^{140}$ Ibid, para 38 .

${ }^{141}$ L Andler, The Secretariat of the Global Environment Facility: From Network to Bureaucracy, in Biermann and Siebenhüner, supra note 53 at 219.
} 
Figure 2: Simplified Representation of the Institutional Scheme for the Access to GEF Funding

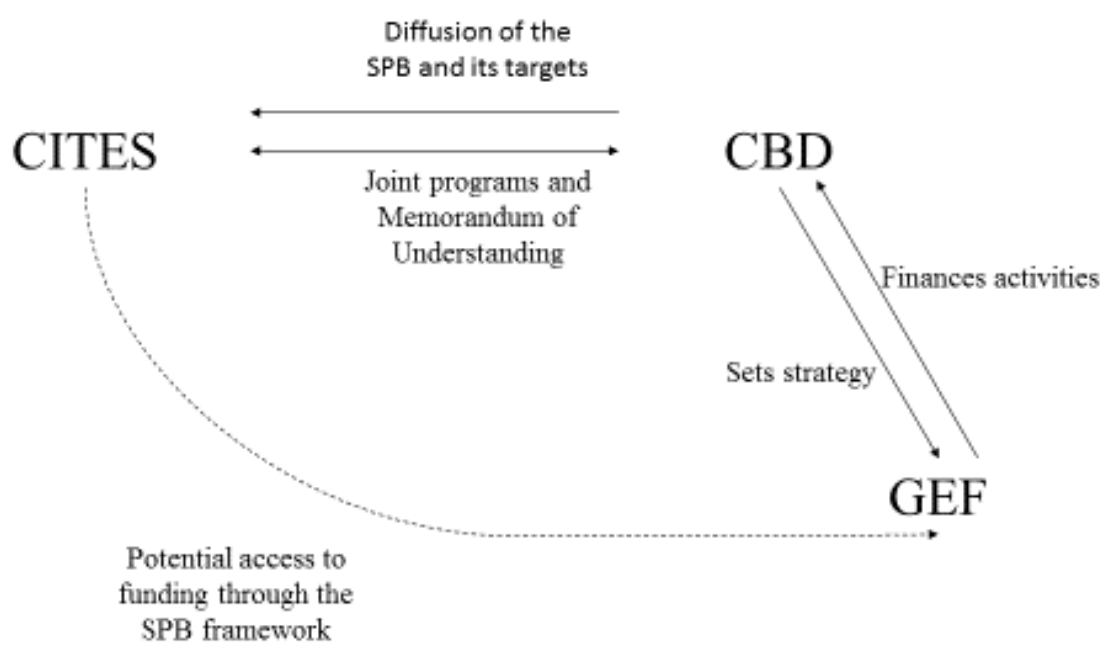

This diagram also shows that MEAs within the biodiversity cluster can no longer be studied separately from other relevant instruments. The ties they have developed over the years mean that, in a vast variety of cases, decision taken in one forum will have repercussions on the other instruments of the cluster and, therefore, on the rights and obligations of the actors of the cluster.

\section{CONCLUSION}

To conclude, this article highlights the fact that biodiversity-related conventions now share a common framework for their actions and that this framework is not only symbolic but can also have concrete effect on the governance of biodiversity. It also illustrates that this common framework was strongly supported by the Secretariats, which are influential autonomous actors in global environmental governance. Finally, it stresses that while the CBD does not have a higher legal value (as provided for in Article 22 of the convention), its political influence in the biodiversity cluster now seems to be at its peak. 
However, even though this situation appears to be a success in the synergistic effort of the biodiversity cluster, one can only remain cautious when considering its outcome on the state of global biodiversity and ecosystems. In October 2014 in Pyeong-Chang, it was clear that the 2020 objectives were far from being attained. ${ }^{142}$ Only a few NBSAPs had been revised in order to integrate the SPB and its targets, and the discussions were mainly focused on financial issues. ${ }^{143}$ How useful can this common framework be if the current state of biodiversity and ecosystems continues to worsen? As emphasized by the UNEP-WCMC in its report on synergies in the biodiversity cluster, the synergetic process must be led by states in order to be truly efficient as a tool for the conservation and sustainable use of biodiversity and ecosystems. ${ }^{144}$ Considering the results of the Pyeong-Chang COP, states are not sufficiently involved in this effort. For instance, this is particularly true concerning Latin American states that have a very low degree of policy coherence in the implementation of the biodiversityrelated conventions. ${ }^{145}$

When studying international environmental law and the existing governance systems, it is all too easy to succumb to pessimism. Focusing on the flaws of such a complex and fragmented system is relatively effortless compared to finding workable solutions to its shortcomings. Following this analysis, another question should then be: can the SPB as a global framework be of any use for the state of the environment? In her 1999 paper entitled 'Leverage Points, Places to Intervene in a System,' Donella Meadows identified 'the goals of the system' as one of twelve ways to effectively modify the functioning of a system. ${ }^{146}$ With the wide diffusion of the SPB and its Aichi Biodiversity Targets, supported by a strong collaboration of the Secretariats and other institutions in the field of biodiversity, the biodiversity cluster now has a clear and common goal. However, as underlined by Meadows, the goals of a system 'are not so much deductible from what anyone says as from what the system does.'

By comparing the behaviour of the different actors of the systems, it seems that there is a disconnection between the perceived goals. While institutions are trying to establish a comprehensive and efficient set of goals, states act in order to maximize their interests and reduce their costs. This situation is symptomatic of global environmental instruments where

\footnotetext{
${ }^{142}$ CBD, Global Biodiversity Outlook 4 (2014) at 10: 'However, in most cases this progress will not be sufficient to achieve the targets set for 2020, and additional action is required to keep the Strategic Plan for Biodiversity 2011-2020 on course.'

${ }^{143}$ IDDRI, La Conférence Biodiversité en 2014: décisions et pistes d'action (2014).

${ }^{144}$ UNEP-WCMC, supra note 11 at 16.

${ }^{145}$ Gomar, Stringer, and Paavola, supra note 40.

${ }^{146}$ D Meadows, Leverage Points Places to Intervene in a System (1999).
} 
negotiations tend to water down obligations. For instance, the CBD does not have the legal tools to match its ambitions. Still, while the legal obligations it entailed have grown weaker, its political influence has strengthened. As a result, the SPB has spread to other instruments that have clearer legal obligations, such as CITES. In this situation, there is a hope that MEAs having a greater effectiveness may help in achieving some of the targets set in the SPB.

Moreover, states are now under both a top-down and bottom-up influence. This article has focused on the SPB within the biodiversity cluster, but with its incorporation in the Rio+20, the strategic plan and its targets have gained momentum and are now omnipresent on the international agenda for the global environment. The current discussions within the CBD are focusing on how to link the post-2015 sustainable development goals with the strategic plan. ${ }^{147}$ The work program of the newly established IPBES was also specifically designed in order to contribute to the SPB. The international push towards the achievement of the Aichi Biodiversity Targets is clear. It appears that all of the relevant actors at the international level now share the same reference point. ${ }^{148}$ In addition, the growing involvement of civil society adds a bottom-up influence to this top-down push towards the achievement of the SPB. Nongovernmental organizations are influential actors within the different regime complexes for environmental governance, and they have also adopted the SPB as a framework for actions. ${ }^{149}$ This set of influences may provide incentives that are sufficient enough to induce positive reactions from the states. The more incentives the states will have for conservation and sustainable use of biodiversity and ecosystems, the more likely it is that the SPB will be a success. The diffusion of the SPB has helped to strengthen and align those incentives; the hope is that this will lead to better biodiversity conservation results in the future.

\footnotetext{
${ }^{147}$ For more details, see CBD, <https://www.cbd.int/idb/2015/goals/>.

${ }^{148}$ P. Muller, Les Politiques Publiques (2013) at 55. The referential is understood as the representation of the reality on which one wishes to intervene. In the case of the global governance of biodiversity and ecosystems, it can be said that all relevant actors now share the SPB as a referential. They share the same perception of the threats on biodiversity and ecosystems and of the necessary actions needed to reduce those threats.

${ }^{149}$ For instance, see the declaration of the World Wildlife Fund, <http://wwf.panda.org/what_we_do/how_we_work/policy/conventions/cbd/cop12/>.
} 